\title{
Prinsip Dasar Falsafah Akhlak Omar Mohammad Al-Toumy Al- Syaibany dan Implikasinya dalam Pendidikan di Indonesia
}

\author{
Tatang Hidayat ${ }^{*}$, Syahidin ${ }^{1}$, Ahmad Syamsu Rizal ${ }^{1}$ \\ 1Prodi Pendidikan Agama Islam Sekolah Pascasarjana Universitas Pendidikan Indonesia
}

\section{ARTICLE INFO}

\section{Keywords}

Falsafah Akhlak, Indonesia, Omar

Mohammad Al-Toumy Al-

Syaibany, Pendidikan.

*Correspondence

tatanghidayat@upi.edu

\section{Article History}

Received 31 Agustus 2018

Accepted 1 Maret 2019

Published online 28 Maret 2019

\author{
ABSTRACT
}

Tulisan ini bertujuan membahas prinsip-prinsip dasar falsafah akhlak Omar Mohammad Al-Toumy Al-Syaibany dan implikasinya dalam pendidikan di Indonesia. Pendekatan pembahasan menggunakan metode kualitatif dan studi literatur. Berdasarkan hasil pembahasan, prinsip dasar akhlak Omar Mohammad Al-Toumy AlSyaibany terdiri dari 6 prinsip. Pertama, percaya pentingnya akhlak dalam hidup. Kedua, percaya bahwa akhlak itu sikap yang mendalam dalam jiwa. Ketiga, percaya bahwa akhlak ialah mencapai kebahagiaan dunia dan akhirat bagi individu dan masyarakat. Keempat, percaya tujuan akhlak ialah mencapai kebahagiaan dunia dan akhirat bagi individu dan masyarakat. Kelima, percaya akhlak itu sesuai dengan fitrah manusia. Keenam, percaya teori akhlak tidak sempurna kecuali ditentukan sebagian konsep-konsep asas seperti akhlak hati nurani, paksaan akhlak, hukum akhlak, tanggung jawab akhlak, dan ganjaran akhlak. Implikasinya, pendidikan akhlak sangat penting untuk dijadikan instrumen pokok dalam menentukan kebijakan pada semua jenjang pendidikan di berbagai institusi pendidikan.

This paper aims to discuss the basic principles of akhlaq philosophy of Omar Mohammad Al-Toumy Al-Syaibany and its implications in education in Indonesia. The discussion approach uses qualitative methods and literature studies. Based on the results of the discussion, Omar Mohammad Al-Toumy Al-Syaibany's basic prinsiples of akhlaq consist of 6 principles. First, believe in the importance of akhlaq in life. Second, believe that akhlaq is a deep attitude in the soul. Third, believe that akhlaq are to achieve world and the hereafter happiness for individuals and society. Fourth, believe the goal of akhlaq is to achieve happiness of the world and the hereafter for individuals and society. Fifth, believe akhlaq is accordance with human nature. Sixth, believe akhlaq theory is imperfect unless it is determined in part by basic concepts such as akhlaq conscience, akhlaq coercion, akhlaq law, akhlaq responsibility, and akhlaq rewards. The implication is that akhlaq education is very important to be used as the main instrument in determining policy at all levels of education in various educational institutions.

\section{PENDAHULUAN}

Akhlak merupakan salah satu bentuk realisasi dari pengamalan ajaran Islam. Dalam ilmu akhlak, dipelajari berbagai macam sifatsifat mulia seperti jujur, sabar, taubat, syukur, qanā'ah, wara', zuhud, dan sebagainya. Setelah umat Islam mengamalkan ajaran Islam, baik dari aspek akidah, syariah, dan akhlak seharusnya bisa membuahkan akhlak mulia di tengah-tengah kehidupan masyarakat. Tetapi realita kehidupan umat saat ini, khususnya generasi muda di Indonesia sebagai negara mayoritas muslim seolah belum mencerminkan kehidupan yang menjungjung tinggi nilai-nilai akhlak mulia. Hidayat, Rizal, \& Fahrudin (2018) menyatakan bahwa generasi muda Indonesia saat ini tengah mengalami krisis moral. Setiap tahun angka kenakalan remaja semakin meningkat seperti meningkatnya konsumsi minuman keras, konsumsi narkoba, pergaulan bebas, hamil di luar nikah, aborsi, tawuran pelajaran, dan masih banyak yang lainnya.

Murdaningsih (2015) melaporkan dalam republika.co.id (9/3/2015) bahwa pada 2007 berdasarkan Riset Kesehatan Dasar Departemen Kesehatan jumlah remaja pengonsumi minuman keras di Indonesia masih diangkat 4,9 persen. Namun pada 2014 berdasarkan hasil riset yang dilakukan Gerakan Nasional Anti Miras (GeNAM) tercatat ada lonjakan drastis tingkat konsumsi minuman keras hingga menyentuh angka 23 persen yakni 14,4 juta orang dari total jumlah remaja Indonesia yang saat ini berjumlah 63 juta. 
Berdasarkan catatan Direktorat Reserse Narkoba Polda Metro Jaya, jumlah pengguna napza kalangan remaja di DKI Jakarta dalam tiga tahun terakhir mengalami peningkatan. Pada tahun 2011, siswa SMP pengguna napza berjumlah 1.345 orang. Tahun 2012 naik menjadi 1.424 orang, sedangkan pengguna baru pada Januari-Februari 2013 tercatat 262 orang. Di kalangan SMA, pada 2011 tercatat 3.187 orang, tahun berikutnya menjadi 3.410 orang. Adapun kasus baru tahun 2013 tercatat 519 (kompas.com, 7/3/2013).

Kasus pergaulan bebas pun terus meningkat, bukan hanya terjadi di kota-kota besar seperti Jakarta, Bandung, Yogyakarta, Semarang, Surabaya dan yang lainnya, tetapi sudah terjadi juga di kota kecil seperti Ponorogo. Subekhi (2016) melaporkan dalam sindonews.com (9/8/2016) tercatat hingga bulan Juni 2016 setidaknya ada 47 siswi SMA dan SMP yang hamil akibat seks bebas yang mereka lakukan. Data di Pengadilan Agama, Kabupaten Ponorogo, ada 47 pelajar SMA dan SMP yang hamil serta putus sekolah. Kasus pelajar hamil di Ponorogo mengalami peningkatan diibanding sepanjang tahun 2015 yang berjumlah 56 kasus, sementara sampai Juni 2016 sudah ada 47 kasus.

Sementara itu, angka abrosi dan jumlah pengidap infeksi HIV/AIDS juga terus mengalami peningkatan. Berdasarkan data Badan Koordinasi Keluarga Berencana Nasional (BKKBN), tahun 2010 sebanyak 2 juta remaja melakukan aborsi (viva.co.id (20/6/2012). Adapun Kementrian Kesehatan pada Oktober 2013 menunjukkan, dari Juli sampai dengan September 2013 jumlah infeksi HIV baru yang dilaporkan sebanyak 10.203 kasus, sedangkan jumlah kasus baru AIDS yang dilaporkan sebanyak 1.983 kasus. Dari kasus tersebut, kalangan remaja salah satu yang mendapat porsi cukup besar (kompas.com, 24/1/2014). Di sisi lain, angka tawuran pelajar pun tiap tahun terus mengalami peningkatan. Berdasarkan catatan Komisi Nasional Perlindungan Anak, sepanjang 2013 ini terjadi 255 kasus tawuran pelajar di Indonesia. Angkat tersebut dinilai meningkat disbanding tahun 2012 yakni sebanyak 147 kasus (tribunnews.com, 22/12/2013).

Problematika yang dipaparkan di atas merupakan bukti nyata bahwa generasi muda Indonesia sedang mengalami krisis akhlak. Jika problematika ini tidak diselesaikan, akan berimbas kepada pembangunan negeri ini di masa depan. Bukan hal yang mustahil jika problematika generasi muda saat ini tidak dicarikan solusi, suatu saat negeri ini akan dipimpin oleh orang-orang yang memiliki krisis akhlak. Tentunya banyak faktor yang menyebabkan generasi muda saat ini jauh dari nilai-nilai akhlak. Hidayat \& Suryana (2018) melaporkan penyebab problematika generasi muda saat ini tidak bisa dilepaskan dari krisis multidimensional yang melanda Indonesia, salah satunya problematika pendidikan. Sistem pendidikan materialisme yang diterapkan di negeri ini belum mampu membangun generasi yang berakhlak mulia, buktinya output dari pendidikan saat ini belum mampu membina generasi muda yang memiliki karakter akhlak mulia, karena output dari sistem pendidikan materialisme hanya mengukur kesuksesan dari aspek materi.

Di sisi lain, faktor lain yang menyebabkan krisis akhlak generasi muda Indonesia di antaranya belum pahamnya generasi muda muslim terhadap ajaran Islam yang dianutnya, kurangnya pendidikan dari keluarga, karena masih banyak anak-anak yang belum mendapatkan pendidikan agama yang baik di lingkungan keluarganya. Kurangnya pengawasan dari lingkungan masyarakat, buktinya kehidupan sosial di masyarakat cenderung individualistik, dan kurangnya peran negara dalam menjaga ketakwaan individu rakyatnya, karena sistem kehidupan yang diterapkan di negeri ini adalah sistem kehidupan sekuler yang memisahkan agama dengan kehidupan. Berdasarkan penyebab problematika sebagaimana yang diuraikan di atas, belum pahamnya generasi muda muslim terhadap ajaran Islam yang dianutnya terutama berkaitan dengan akhlak mulia menarik kiranya untuk dikaji.

Oleh karena itu, perlu kiranya konsep akhlak ini dipahami dan diamalkan oleh kalangan generasi muda. Berangkat dari hal ini, penulis berasumsi dengan memahami prinsip dasar falsafah akhlak Omar Mohammad Al-Toumy Al-Syaibany bisa memberikan pemahaman yang utuh dan komprehensif terhadap pendidikan di Indonesia.

\section{PRINSIP DASAR FALSAFAH AKHLAK OMAR MOHAMMAD AL-TOUMY AL-SYAIBANY}

\subsection{Pentingnya Akhlak dalam Hidup}

Akhlak seorang muslim mesti berpegang teguh kepada ajaran Islam, hal demikian harus dipelihara bukan hanya terhadap makhluk, tetapi juga terhadap Allah Subhānahu Wa Ta'ālā yang implementasinya dalam akidah dan ibadah (Al-Syaibany, 1979:312). Namun mesti dipahami dari sekian banyak definisi tentang akhlak yang dipaparkan para ahli, salah satunya alSyaibany, fenomena pengamalan sifat akhlak dalam kehidupan bermasyarakat belum seutuhnya dapat kita temukan. Hal yang demikian karena yang membentuk masyarakat bukan hanya akhlak, tetapi memerlukan pemikiran, perasaan, dan aturan hidup sama yang diterapkan di tengah-tengah masyarakat. Adapun akhlak merupakan buah dari pengamalan ajaran Islam yang dilakukan oleh setiap individu.

Pentingya akhlak tidak terbatas pada seorang saja, tetapi penting untuk masyarakat, umat, dan seluruh manusia. Sebagaimana seseorang tidak sempurna kemanusiaannya tanpa akhlak, begitu juga masyarakat tidak baik keadaannya dan makna hidupnya tanpa memiliki akhlak (Al-Syaibany, 1979:318). Dengan demikian, kehidupan bermasyarakat tidak akan baik jika setiap individu dalam masyarakat tersebut tidak memiliki akhlak mulia. Oleh karena itu, pentingya dalam kehidupan bermasyarakat untuk memiliki pemikiran, perasaan, dan aturan hidup yang sama untuk diterapkan di tengah-tengah mereka. Karena akhlak ini merupakan ciri khas dari Islam, maka aturan hidup yang harus diterapkan di tengah-tengah kehidupan masyarakat pun mesti peraturan hidup yang berasal dari Islam, bukan yang lain.

\subsection{Akhlak Sikap yang Mendalam dalam Jiwa}

Akhlak adalah sikap yang mendalam dalam jiwa, yakni sikap yang terlahir dari bentuk kesadaran hubungan hamba dengan khalik.. Ia juga suatu faktor yang mempengaruhi tingkah laku manusia dan untuk menyesuaikan dirinya dengan alam sekitar tempat ia hidup. Akhlak bukan sekedar kata-kata yang diulang-ulang dan slogan yang dipamerkan, tetapi ia adalah watak, kebiasaan, sikap yang mendalam dijiwai, bekerja sama dalam membentuknya. Adapun berbagai faktor warisan yang merupakan kecerdasan, naluri, dan temperamen serta faktor-faktor alam sekitar tergambar dalam pendidikan pengajaran, bimbingan, dan latihan. Sehingga akhlak bisa dibina melalui pendidikan, riyāḍaћ dan mujāhadah (Al-Syaibany, 1979:319-320).

\subsection{Akhlak Mencapai Kebahagiaan Dunia dan Akhirat Bagi Individu dan Kebaikan Masyarakat}

Akhlak sesuai dengan fitrah, akal yang sehat, memenuhi kebutuhan-kebutuhan perseorangan yang baik, masyarakat yang mulia dalam segala waktu, tempat dan mengatur segala hubungan manusia dengan orang lain. Diantara faktor yang menyebabkan 
akhlak berhak mendapat penghargaan karena akhlak memenuhi kebutuhan-kebutuhan perseorangan dan kumpulan-kumpulan di setiap waktu dan tempat, sebab ia bersifat menyeluruh, luas, seimbang, sederhana, realistis, mudah, berhubungan antara akidah dan amal, antara kata dan perbuatan, antara teori dan praktek, tetap dalam dasar-dasar dan prinsip-prinsip umum di samping tidak menentang segala kemajuan yang berguna dan perkembangan yang baik (Al-Syaibany, 1979:324).

\section{Ciri-ciri dan keistimewaan akhlak diantaranya :}

\subsubsection{Ciri-ciri sifat menyeluruh (Universal)}

Akhlak memiliki sifat menyeluruh (universal) dari segi konsepnya, karena berkaitan dengan syariah Islam. Akhlak dijadikan suatu metode (manhaj) yang sempurna, meliputi seluruh gejala aktivitas biologis perorangan dan masyarakat. Hal itu meliputi segala hubungan manusia, segala segi kehidupannya dan segala segi hubungannya dengan kehidupan dan benda-benda hidup. Pengawasan Allah Subhānahu Wa Ta'ālā yang menjadi dasar akhlak tidak hanya menyentuh suatu perbuatan dan meninggalkan yang lain, tetapi menyentuh seluruh perbuatan, mulai dari sembahyang seorang muslim dihadapan Allah Subhānahu Wa Ta'ālā sampai kepada pekerjaan dan profesi yang dikerjakannya karena menjalankan kewajiban hidup (Al-Syaibany, 1979:324-325).

Akhlak mengandung pengertian yang luas dan menyeluruh berbeda keakar-akarnya dengan yang terdapat dalam agama Kristen dan agama-agama yang lain. Islam dengan ajaran dan akhlaknya menyatukan secara terpadu antar iman, ibadah, dan mu'ämalah kemasyarakatan. Artinya tidak memisahkan sama sekali antara urusan ibadah dan kemasyarakatan. Islam yang berdasarkan Alquran dan Sunnah menaruh perhatian pada tingkal laku masyarakat yang bersifat akhlak, pada kehidupan perundang-undangan, politk, dan ekonomi sebagaimana ia menaruh perhatian pada agama, apalagi pada alam perasaan. Islam menyentuh dalam seluruh aspek kehidupan sehari-hari, yakni segala sesuatu berlaku pengawasan Allah Subhānahu Wa Ta'ālā (Al-Syaibany, 1979:325).

\subsubsection{Ciri-Ciri Keseimbangan}

Akhlak menghargai berbagai kebutuhan manusia dan segala tuntutan hidup. Ia menghargai tabiat manusia yang terdiri atas badan dan ruh, menimbangkan tuntutan-tuntutan jasmani dan jiwa, tuntutan-tuntutan dunia dan akhrat. Dengan kata lain akhlak tidak mengorbankan kepentingan jasmani untuk kepentingan rohani, juga nilai-nilai kebendaan untuk kepentingan nilai kerohanian (Al-Syaibany, 1979:328).

Ajaran Islam memberi hak bagi setiap segi dan meletakkannya pada tempat yang harus diletakkan ia padanya tanpa berlebihan atau berkurang. Islam dengan ajaran dan akhlaknya menyentuh manusia secara keseluruhan dan lengkap melengkapi. Ia menaruh perhatian pada jasmani dan akalnya sebagaimana ia memperhatikan rohaninya. Ia menggabungkan antara tuntutan-tuntutan kebendaan dan tuntutan-tuntutan spiritual dan menaruh perhatian pada kemashlahatan dunia sebagaimana ia memperhatikan kemaslahatan akhirat (Al-Syaibany, 1979:328).

Islam dengan keseimbangan dan lengkap melengkapi di antara tuntutan jasmani dan rohani, serta antara tuntutan dunia dan akhirat telah terlepas dari dualisme dan pertentangan antara kedua macam tuntutan pada setengah-setengah agama dan aliranaliran filsafat seperti agama Yahudi dan mazhab-mazhab materialisme yang mengarah ke arah materialisme. Serta antara spiritualistik dan aliran-aliran sufiah ekstrim yang mengarah kepada kerohanian yang melampaui bagi setengahnya (AlSyaibany, 1979:330).

\subsubsection{Ciri-Ciri Sederhana}

Ciri kesederhanaan dan tidak berlebihan pada salah satu arah di antara segala arah, memandang kepada perkara-perkara itu dengan jalan tengah, tanpa berlebihan. Dengan memiliki akhlak, manusia bisa hidup sederhana. Ia tidak kejam kepada dirinya, sehingga ia menjadikannya jalan hidupnya, dan tidak memberi dirinya lebih banyak dari haknya dalam kesenangan, sehingga ia menjadi hewan (Al-Syaibany, 1979:330-331).

Gambaran yang paling baik diberikan kepada orang-orang yang beriman ialah mereka dijadikan umat pertengahan dan tidak berlebih-lebihan dalam segala urusannya, seperti tidak bakhil dan menghalangi bila perlu diberi pengorbanan diperlukan. Jalan tengah dalam Islam inilah yang menggabungkan dua ujung keseimbangan tanpa berlebihan dan kekurangan. Dengan begitu, manusia menjadi normal susunannya, kekuatannya selaras dan tidak berlebih-lebihan minatnya (Al-Syaibany, 1979:331-333).

\subsubsection{Ciri-Ciri Realisme}

Akhlak sesuai dengan kemampuan kemanusiaan dan sejalan dengan naluri yang sehat. Di antara gejala-gejala realisme pada akhlak ialah menghormati tuntutan-tuntutan ruh dan jasmani sekaligus, tidak membebankan pada manusia apa yang melebihi daya dan kemampuannnya. Ia tidak meminta kepada manusia mengorbankan kebutuhan-kebutuhan jasmaninya yang darurat dan naluri syahwatnya yang sederhana. Ia tidak mengajak manusia untuk zuhud yang berlebihan dengan meninggalkan dunia semuanya. Sebaliknya akhlak dalam ajaran Islam pada umumnya meminta manusia untuk menikmati apa yang diberikan Allah Subhānahu Wa Ta'ālā kepadaya dari kenikmatan dunia dalam batas-batas yang masuk akal, dan jangan ia meninggalkan bagiannya di dunia ini (Al-Syaibany, 1979:333-334).

Umat Islam diperintahkan untuk mencari rezeki dan bersungguh-sungguh mencarinya selama mencarinya dengan cara dan jalan yang halal. Ia harus kuat dalam kebenaran, membalas setiap orang yang ceroboh kepadanya dengan jalan setimpal. Adapun orang yang berbuat zuhud dan mengharamkan usaha mencari rezeki, maka ia telah berbuat aniaya. Sebab, ia tidak dapat meminta tolong kepada manusia lain untuk memenuhi kebutuhan-kebutuhan jasmaninya (Al-Syaibany, 1979:334-336).

\subsubsection{Ciri - Ciri Kemudahan}

Ciri kemudahan dan memberatkan. Manusia tidak diberati kecuali dalam batas-batas kesanggupan dan kekuatannya. Ia tidak dianggap bertanggung jawab dari segi akhlak dan syara' kecuali jika berada dalam keamanan, kebebasan, dan kesadaran akal yang sempurna. Banyak prinsip-prinsip syariah Islam dan kaidah ushul fikih yang menguatkan prinsip kemudahan dan mengangkat paksaan dalam syariah Islam, seperti kaidah dalam ushul fikih bahwa "Darurat membolehkan yang terlarang," "Kesusahan membolehkan kemudahan," dan "Keperluan menepati tempat darurat" (Al-Syaibany, 1979:336).

Namun kemudahan yang menjadi ciri akhlak tidak berarti memudah-mudahkan urusan agama atau menganjurkan kebebasan seluas-luasnya sehingga hukum halal dan haram dianggap mudah. Telah kita pahami dalam ushul fikih, bahwa di 
antara prinsip-prinsip syariah Islam juga ada prinsip-prinsip cadangan yang menjaga supaya jangan jatuh dalam lembah kemaksiatan dan menganggap mudah urusan halal dan haram. Diantara pirnsip-prinsip ini adalah "Darurat dinilai menurut kadarnya" juga prinsip "menjaga syubhat" dan prinsip "sesuatu yang membawa kepada keharaman maka sesuatu itu menjadi haram". Artinya segala sesuatu yang menjadi jalan kepada barang yang haram maka ia juga haram (Al-Syaibany, 1979:336-340).

\subsubsection{Ciri - Ciri Mengikat Perkataan dengan Amal}

Tidak ada nilai iman yang tidak diikuti oleh akal. Tidak ada orang yang mengatakan bahwa agama dan akhlak hanyalah sekedar perkataan yang diulang-ulang atau slogan yang dipamerkan, tetapi selalu berkaitan antara perkataan dan amal. Dengan demikian, perkataan orang-orang yang beriman dalam menyeru kebaikan mesti selaras dengan amalnya (Al-Syaibany, 1979:344).

\subsubsection{Ciri-Ciri Tetap Dalam Dasar-Dasar Dan Prinsip - Prinsip Akhlak Umum}

Waktu dalam geraknya dan masyarakat dalam perkembangannya tidak akan merubah ketatapan akhlak itu. Yang berubah hanyalah kebiasaan dan tradisi yang diciptakan oleh manusia sendiri sebab ia rusak dan hancur. Adapun nilai-nilai akhlak yang tinggi yang dibawa oleh agama yang benar tidak berubah, sebab ia berhadapan dengan rencana khittah manusia yang tidak berubah. Ia termasuk perkara-perkara tetap dan kekal yang disekelilingnya benda dan manusia bergerak (Al-Syaibany, 1979:345).

Kita tidak diperintahkan agar nilai-nilai akidah dan akhlak harus cocok dengan perubahan-perubahan peradaban (tamaddun) dan masyarakat, bahkan masyarakatlah yang harus sesuai dengan nilai-nilai akidah dan akhlak yang kekal dan tetap. Ciptaan Allah Subhānahu Wa Ta'ālā yang telah dijadikan manusia atasnya tidak ada perubahan atas ciptaan Allah Subhānahu Wa Ta'ālā. Allah Subhānahu Wa Ta'ālā mengajak supaya kita mengubah diri jika kita ingin mengubah masyarakat. Jadi jalan perbaikan, kemenangan, dan perubahan dari lemah menjadi kuat, terlatak pada kemauan untuk berubah (Al-Syaibany, 1979:345-346).

\subsection{Tujuan Akhlak Mencapai Kebahagiaan Dunia dan Akhirat Bagi Individu dan Kebaikan Masyarakat}

Tujuan tertinggi agama dan akhlak ialah menciptakan kebahagiaan dunia dan akhirat, kesempurnaan jiwa bagi individu, menciptakan kebahagiaan. kemajuan, kekuatan, dan keteguhan bagi masyarakat. Akhlak tidak terbatas tujuannya untuk mencapai kebahagiaan akhirat yang tergambar dalam mendapat keridaan, ampunan, rahmat, pahala, dan juga mendapatkan kenikmatan akhirat yang telah dijanjikan oleh Allah Subhānahu Wa Ta'ālā kepada orang -orang bertakwa. Tetapi terintegrasi antara kehidupan di dunia dan akhirat. Di antara yang termasuk kebahagiaan dunia berkenaan dengan masyarakat adalah kuatnya masyarakat, kukuhnya kemajuannya yang terus menerus, perpaduannya, kestabilannya, sifat tolong menolong antara anggotanya, solidaritas antara anggotanya, keikhlasan bekerjanya, rasa tanggung jawab terhadap masyarakat, sifat lurusnya, kesadaran mereka terhadap masalah-masalah masyarakat mereka, dan lain-lain gejala kebahagiaan masyarakat (Al-Syaibany, 1979:346-347).

Untuk mencapai tujuan akhlak dalam menggapai kebahagiaan di dunia dan akhirat baik bagi kehidupan individu dan masyarakat diperlukan aturan Islam yang mengikat masyarakat. Akhlak merupakan buah dari pengamalan ajaran Islam yang terintegrasi baik aspek akidah, syariah, dan akhlak. Oleh karena itu, diperlukan juga aturan Islam yang mengikat di tengahtengah kehidupan masyarakat, dan ini merupakan konsekuensi dari penerapan aturan Islam dalam seluruh aspek kehidupan. Dari sana akan terlahir tujuan akhlak yang sesungguhnya, yakni kebahagiaan dunia dan akhirat bagi individu dan masyarakat.

\subsection{Akhlak Kemanusiaan Yang Sesuai Dengan Fitrah Manusia}

Islam adalah sumber terpenting terhadap prinsip-prinsip, dasar-dasar, nilai-nilai, dan teladan akhlak yang terkandung di dalamnya. Ia adalah sumber terpenting bagi akhlak, hati nurani, dan kesadaran akhlak. Ia sumber terpenting yang menentukan baik buruk yang mengandung keputusan akhlak (moral judgement) terhadap perbuatan manusia. Ia juga sumber terbaik dari mana kita ambil ukuran-ukuran akhlak dan kita bina hukum-hukum akhlak saja. Orang Islam, dengan petunjuk agamanya, mengikat akhlak dengan agama dengan ikatan yang kukuh. Ia memandang akhlak sebagai bagian yang tidak terpisah dari agama (Al-Syaibany, 1979:355).

\subsection{Konsep Asas Akhlak}

Teori akhlak tidak akan sempurna kecuali jika didalamnya ditentukan lima segi pokok : Hati nurani akhlak (akhlaq conscience), paksaan akhlak (akhlaq obligation), hukum akhlak (akhlaq judgement), tanggung jawab akhlak (akhlaq responsibility), dan ganjaran akhlak (akhlaq rewards). Sebab segi-segi ini merupakan unsur-unsur pokok bagi setiap teori akhlak. Jadi haruslah setiap orang yang ingin membina teori serupa ini untuk menentukan sikap terhadap segi-segi ini, kemudian ini menentukan makna, sumber-sumber, ukuran-ukuran, syarat-syaratnya, dan lain-lain yang berhubungan dengannya (Al-Syaibany, 1979:363).

\subsubsection{Hati Nurani Akhlak (Akhlaq Conscience)}

Ta'rif yang paling sederhana yang dapat disebutkan tentang hati-nurani dan sesuai dengan jiwa Islam adalah ta'rif yang mengatakan "ia adalah dorongan yang mengawasi dari dalam, perbuatan-perbuatan manusia yang nampak dari luar, sehingga ia dapat menentukan berlaku atau tidaknya perbuatan-perbuatan itu". Atau boleh juga "ia adalah pusat bimbingan pada manusia yang menasehati, membimbing, mengendalikan niat, maksud, perbuatan-perbuatannya, menerangi hubungannya dengan orang lain, dan hubungannya dengan Tuhan-Nya." Atau boleh juga "perasaan jiwa dari dalam di mana terpantul perbuatan-perbuatan manusia sehingga ia dapat menghargai perbuatan-perbuatan ini dan sanggup ia menentukan apakah ia baik atau buruk." Ini semuanya ta'rif dan tafsir yang mungkin terhadap hati nurani akhlak dan tidak berbeda maknanya jika diperhatikan betul-betul (Al-Syaibany, 1979:363-364).

\subsubsection{Paksaan Akhlak (Akhlaq Obligation)}

Tidak ada nilai bagi prinsip dan dasar-dasar akhlak jika ia tidak mengandung kesanggupan memaksa manusia mengikutinya, berpegang teguh dalam melaksanakannya, dan beramal sesuai dengannya. Jika paksaan ini timbul pada mulanya, biasanya dari kekuasaan di luar dari seseorang, maka akhlak seseorang tidak sempurna kecuali jika paksaan itu timbul dari dalam, sehingga ia mendapati dirinya terdorong mengikuti prinsip_prinsip akhlak itu dan berpegang teguh mengamalkannya dengan penggerak- 
penggerak dan dorongan-dorongan dari dalam, yang dirasa bergerak ke arah tujuan yang dicari dengan mudah, gampang dan penuh kekuatan (Al-Syaibany, 1979:368).

\subsubsection{Hukum Akhlak (Akhlaq Judgement)}

Hukum akhlak yang dimaksud adalah menghargai nilai-nilai akhlak bagi perbuatan manusia sekedar unsur-unsur kebaikan dan keburukan yang terkandung didalamnya. Jadi hukum akhlak ini harus memiliki norma-norma yang menjadi dasarnya. Bagi seorang muslim, ia tidaklah ke luar dari prinsip-prinsip dan dasar-dasar akhlak yang umum yang dibawa oleh agama Islam dan terkandung dalam perintah-perintah dan larangan-larangannya. Ini berdasar pada prinsip bahwa syara' adalah sumber hukum terhadap baik dan buruknya perbuatan manusia, yang baik ialah yang dianggap baik oleh syara dan yang buruk ialah yang dianggap buruk oleh syara (Al-Syaibany, 1979:373-374).

\subsubsection{Tanggung Jawab Akhlak (Akhlaq Responsibility)}

Mengenai tanggung jawab akhlak, Islam memandangnya sebagai teras amal akhlak, pangkal hukum akhlak, balasan akhlak, dan perkara-perkara yang berhubungan dengannya, seperti pahala, siksaan dengan bentuknya yang bermacam-macam. Ini berarti bahwa kita tidak sanggup memutuskan tentang perbuatan akhlak dan juga tidak dapat memberinya ganjaran akhlak kecuali kalau sudah cukup syarat, unsur-unsur tanggung jawab bagi pemiliknya dan segala penghalangnya sudah lenyap daripadanya (Al-Syaibany, 1979:378).

\subsubsection{Ganjaran Akhlak (Akhlaq Rewards)}

Ganjaran akhlak menurut pandangan Islam dianggap sebagai perkara yang menyempurnakan tanggung jawab akhlak dan hukum akhlak, di mana orang yang memiliki syarat-syarat tanggung jawab akhlak dan sah diberikan padanya sifat baik atau buruk, maka ialah lebih layak menerima ganjaran, baik pahala atau siksaan. Maka tanggung jawab akhlak, hukum akhlak, dan ganjaran akhlak adalah perkara-perkara yang berkaitan antar satu sama lain dan ada hubungan timbal balik, sehingga jika salah satu wujud maka dua perkara yang lain wujud juga (Al-Syaibany, 1979:390).

Berdasarkan uraian di atas, dapat dibuatkan bagan prinsip dasar falsafah akhlak Omar Mohammad Al-Toumy Al-Syaibany diuraikan pada Gambar 1.

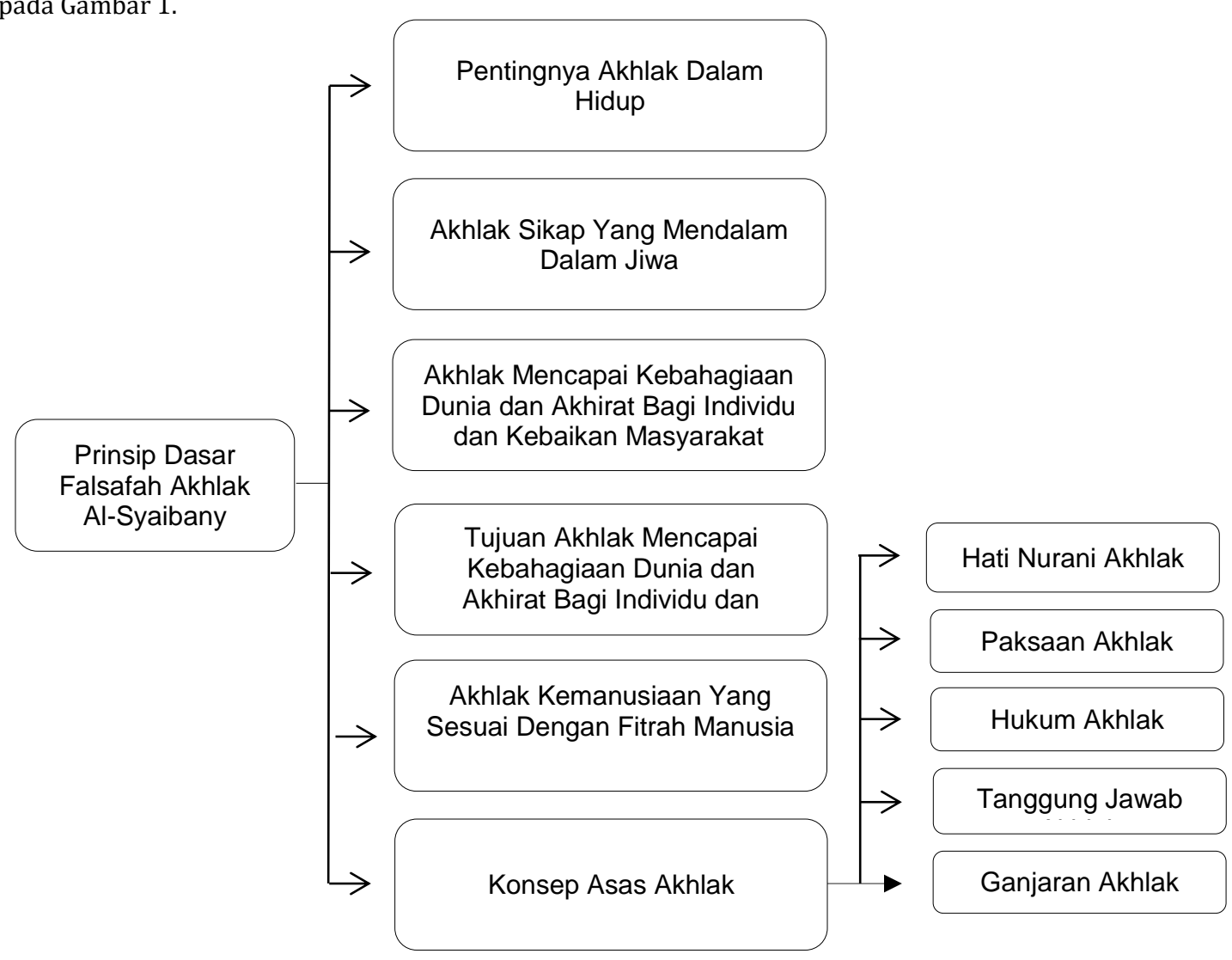

Gambar 1. Prinsip dasar falsafah akhlak Omar Mohammad Al-Toumy Al-Syaibany

\section{IMPLIKASINYA TERHADAP PENDIDIKAN DI INDONESIA}

Falsafah akhlak al-Syaibany terdiri dari beberapa prinsip antara lain : akhlak memiliki posisi penting dalam hidup, akhlak sikap mendalam dalam jiwa, akhlak mencapai kebahagiaan dunia dan akhirat untuk individu dan masyarakat, tujuan akhlak untuk kebahagiaan dunia dan akhirat, akhlak kemanusiaan sesuai dengan fitrah manusia, konsep asas akhlak seperti hati nurani, paksaan, hukum, tanggung jawab, dan ganjaran.

Akhlak merupakan bagian dari hukum syara, jadi ketika seseorang memiliki karakter akhlak yang mulia, itu merupakan buah dari mengamalkan hukum syara'. Misalnya prinsip akhlak memiliki posisi penting dalam hidup, seseorang akan bersikap jujur dalam menjalankan kehidupan sehari-hari, namun sikap jujur tersebut tidak hanya dilakukan karena berdasarkan ada manfaatnya, tetapi jujur memang diperintahkan oleh Allah Subhānahu Wa Ta'ālā dan Rasul-Nya. Sehingga buah dari akhlak tidak akan lepas dari hasil mengamalkan hukum syara', jika tidak dikaitkan dengan hukum syara' maka itu bukan akhlak, tetapi sifat baik saja. 
Pendidikan akhlak diartikan latihan mental dan fisik yang menghasilkan berbudaya tinggi untuk melaksanakan tugas, kewajiban dan tanggung jawab dalam masyarakat selaku hamba Allah Subhānahu Wa Ta'ālā. Jadi pendidikan akhlak merupakan sistem pendidikan yang dapat memberikan kemampuan seseorang untuk memimpin kehidupan dengan nilai-nilai Islam yang telah menjiwai dan mewarnai corak kepribadian (Suherman, 2016). Karakter akhlak mulia tidak bisa terlahir dengan sendirinya, tetapi memerlukan pendidikan yang dilakukan terus menerus sejak kecil. Hal yang demikian akan menyempurnakan akhlak manusia dan menuntunnya untuk meraih kebahagiaan (Rizal \& Anjaryati, 2016).

Oleh karena itu, dalam menanamkan akhlak kepada murid memerlukan waktu sejak dini dan membutuhkan contoh yang akan diteladani, dalam hal ini guru mesti menjadi sosok figur sebagaimana kiai menjadi figur para santrinya (Hidayat, Rizal, \& Fahrudin, 2018a). Maka dari itu, seorang guru mesti memberikan teladan yang baik dalam mengamalkan akhlak dihadapan muridnya. Diharapkan guru tersebut bisa menjadi figur untuk diteladani oleh murid-muridnya.

Setiap guru, apapun materi bidang ilmu yang diasuhnya harus diarahkan untuk terciptanya akhlak yang mulia bagi diri sendiri dan murid-muridnya. Guru tidak hanya mengajarkan materi mata pelajaran yang diampunya saja akan tetapi juga harus memasukan nilai-nilai akhlak dalam pelajaran yang diajarkan (Robiatul Adawiyah, 2017). Untuk mengawali penanaman nilainilai akhlak, murid harus dibekali dengan materi-materi yang berkaitan dengan akhlak di setiap kegiatan pembelajaran meskipun bidang studi yang diajarkan bukan pelajaran akhlak. Karena dengannya akan menimbulkan kesadaran akan keberadaan dirinya dan apa yang harus dilakukannya. Sehingga menuntut pendidik agar bisa membimbing dan mengantarkan peserta didik ke arah yang diinginkan olehnya (Maghfiroh, 2016).

Berangkat dari hal ini, dalam menanamkan pendidikan akhlak bukan hanya kewajiban guru yang mengampu pelajaran akhlak, tetapi semua guru baik yang mengampu mata pelajaran pendidikan kewarganegaraan, sejarah, ekonomi, sosiologi, geografi, biologi, fisika, matematika, seni, penjaskes, dan mata pelajaran lainnya harus memasukan nilai-nilai akhlak dalam proses pembelajarannya. Hal yang demikian selaras dengan tujuan pendidikan nasional yang tercantum dalam Undang-Undang No. 20 tahun 2003, yakni dalam rangka menanamkan keimanan, ketakwaan, dan akhlak mulia.

Implikasinya, pendidikan akhlak mesti dijadikan instrumen pokok di semua jenjang pendidikan formal. Hal yang demikian akan berkontribusi terhadap sikap batin yang mampu mendorong secara spontan bagi terciptanya semua perbuatan yang bernilai baik, sehingga mencapai kesempurnaan dan memperoleh kebahagiaan yang sempurna (al-Sa'adat). Tertanamnya akhlaq al-Karimah pada diri peserta didik. Adanya hubungan yang didasarkan pada cinta kasih antara guru dan murid. Kriteria seorang pendidik dalam pendidikan akhak meliputi bisa dipercaya, pandai, dicintai, sejarah hidupnya jelas, dan tidak tercemar di masyarakat (Saputra, 2014).

Pemahaman terhadap konsepsi yang utuh terkait pendidikan akhlak sangat dibutuhkan khususnya bagi mereka yang terlibat dalam dunia pendidikan. Terlebih jika dikaitkan dengan pendidikan (tarbiyaћ) sebagai sebuah proses yang berkelanjutan sesuai dengan tumbuh dan berkembangnya diri manusia, maka pendidikan akhlak adalah sebuah proses panjang yang tidak dapat dilihat secara parsial (Maulida, 2013)

Untuk mengimplementasikan akhlak sebagai ranah yang dituju dalam pendidikan, mesti ada sebuah perencanaan pembelajaran yang selaras antara tujuan pendidikan dengan tujuan diciptakannya manusia, karena pembelajaran merupakan salah satu proses inti dalam pendidikan formal (Hidayat \& Syafe'i, 2018). Seorang guru mesti mengupayakan pembinaan karakter dalam setiap pembelajarannya dengan mendesain perencanaan pembelajaran yang berdasarkan pada tujuan. Dalam merencanakan pembelajaran guru bisa menggunakan model, pendekatan, strategi, metode, teknik, taktik, dan media yang pada dasarnya prinsip yang digunakan adalah efektivitas dalam mencapai tujuan pembelajaran. Rancangan bentuk belajar di kelas yang dirancang guru adalah untuk menciptakan kondisi agar siswa dapat belajar dengan penuh motivasi (Faida, 2015 ; Hamim, 2014 ; Muthoharoh, 2014).

Di sisi lain, penanaman nilai-nilai akhlak mesti dimulai sejak usia dini karena masa kanak-kanak adalah masa yang paling kondusif untuk menanamkan kebiasaan yang baik (Bafadhol, 2017). Oleh karena itu, peran orang tua memiliki peranan yang sangat sentral dalam membina anaknya, terutama pembinaan sejak dini di rumah maupun di sekolah. Orang tua harus mempunyai metode dalam menanamkan akhlak, agar nantinya bisa mendidik anak dengan baik dan menjadi anak yang șalih salihah. Metode pendidikan akhlak diantaranya adalah metode pembiasaan, metode keteladanan, metode nasihat dan metode perhatian. Kemudian untuk strategi pendidikan akhlak ini dibagi menjadi dua yaitu pendidikan langsung dan pendidikan tidak langsung. Pendidikan langsung diantaranya adalah keteladanan, anjuran, dan latihan. Pendidikan tidak langsung di antaranya adalah larangan, hukuman, hadiah, dan pengawasan (Zamroni, 2017).

Islam memandang kehidupan duniawi sebagai realitas, maka pendidikan harus dilakukan dalam konteks kehidupan kongkrit yang dijalani dan akan dijalani. Diri sebagai wujud individual maupun sosial adalah fakta kehidupan, maka pendidikan harus diarahkan dalam rangka membangun individu sekaligus masyarakat secara bersamaan (Rizal, 2015). Dengan demikian, untuk menciptakan kepribadian yang baik tidak dapat dilakukan sendiri, tetapi harus dilakukan secara bersama atas dasar saling tolong dan saling mencintai, dan sebagai makhluk sosial manusia memerlukan kondisi yang baik dari luar dirinya (Usman, 2001).

Semua ilmu pengetahuan baik ilmu pengetahuan sosial, alam apalagi agama harus diarahkan pada pengabdian kepada Tuhan sehingga apapun materi yang terdapat dalam suatu ilmu tidak boleh lepas dari tujuan pengabdian kepada Allah Subhānahu Wa Ta'ālā (Ernita Dewi, 2011). Manusia mesti mengetahui potensi dirinya untuk kemudian dikembangkan hingga menuju kesebuah kesadaran yang pada akhirnya tercapainya jiwa yang bahagia (sa'ādah) dan taqarrub kepada Allah Subhānahu Wa Ta'ālä (Mahfudhi, 2016). Ketika manusia sudah mengetahui potensi yang ada dalam dirinya, maka disini perlu seorang guru yang akan membimbing untuk mengoptimalkan potensi tersebut. Dalam menjalankan proses bimbingannya, seorang guru harus senantiasa tawakal kepada Allah Subhānahu Wa Ta'ālā dan mengharap ridha-Nya (Lubis, 2012).

Oleh karena itu, untuk mewujudkan murid yang memiliki karakter akhlak mulia, perlu ada upaya bersama dalam mewujudkan pendidikan Islam yang optimal dalam rangka menjadikan manusia yang mulia, dalam hal ini mewujudkan manusia yang memiliki karakter akhlak mulia. Karakter akhlak mulia tidak akan didapatkan manakala di dalam sistem pendidikannya tidak memfasilitasi untuk menuju ke arah sana. Oleh karena itu, diperlukan sistem pendidikan yang mampu memfasilitas untuk terwujudnya lulusan yang memiliki karakter akhlak mulia. Maka disinilah esensi diterapkannya sistem pendidikan Islam yang akan memfasilitasinya, karena akhlak tidak bisa lahir hanya dengan proses pembelajaran saja, tetapi memerlukan pemikiran, perasaan, dan aturan hidup sama yang diterapkan dalam sistem pendidikan.

Namun untuk mewujudkan sistem pendidikan Islam masih terkendala, karena masih diterapkannya sistem kehidupan sekuler yang mengakibatkan pendidikan yang diselenggarakan di negeri ini merupakan pendidikan sekuler juga. Dalam sistem 
kehidupan sekuler, aturan agama jelas-jelas harus dipisahkan dalam kehidupan. Sedangkan dalam ajaran Islam justru agama tidak bisa dipisahkan dalam seluruh aspek kehidupan, termasuk aspek pendidikan. Oleh karena itu, mesti ada upaya sungguhsungguh dari seluruh komponen umat Islam termasuk para ahli pendidikan Islam untuk mewujudkan sebuah sistem pendidikan yang akan melahirkan para pemimpin yang memiliki karakter akhlak mulia.

Langkah pertama harus ada kelompok dari umat Islam yang mengamalkan Islam secara kaffah, tidak hanya menganjurkan untuk terikat pada akhlak. Karena individu-individu yang ada dalam masyarakat merupakan satu kesatuan, bukan individu yang terpisah. Kelompok tersebut harus mengemban dakwah Islam di tengah-tengah masyarakat, mewujudkan pemikiran dan perasaan Islam, serta menunjukkan akhlak mulia, serta menjauhi akhlak tercela. Dengan cara demikian, seuruh anggota masyarakat akan memiliki akhlak, setelah mereka berbondong-bondong kembali dalam mengamalkan ajaran Islam secara kaffah (Abdurrahman, 2018:243).

Berdasarkan uraian di atas dapat dipahami, akhlak tidak terlahir hanya dengan memusatkan tujuan pendidikan kepadanya, tetapi akhlak merupakan buah dari pengamalan ajaran Islam secara kaffah. Untuk membina akhlak mulia tidak cukup hanya difokuskan kepada individu saja, tetapi mesti ada aturan yang mengikat dalam kehidupan bermasyarakat, yang didalamnya ada pemikiran, perasaan, dan aturan hidup yang sama, yakni Islam. Akhlak terlahir dari implementasi pengamalan ajaran Islam yang dilakukan baik individu dan masyarakat. Dalam konteks pendidikan, mesti ada sistem pendidikan yang terlahir berdasarkan pemikiran, perasaan,dan peraturan hidup yang sama yakni Islam. Dengan cara demikian pendidikan di Indonesia akan lebih baik dan bisa melahirkan calon-calon pemimpin yang akan memimpin dunia dan memiliki akhlak mulia. Berdasarkan uraian di atas, dapat dibuatkan Gambar 2.

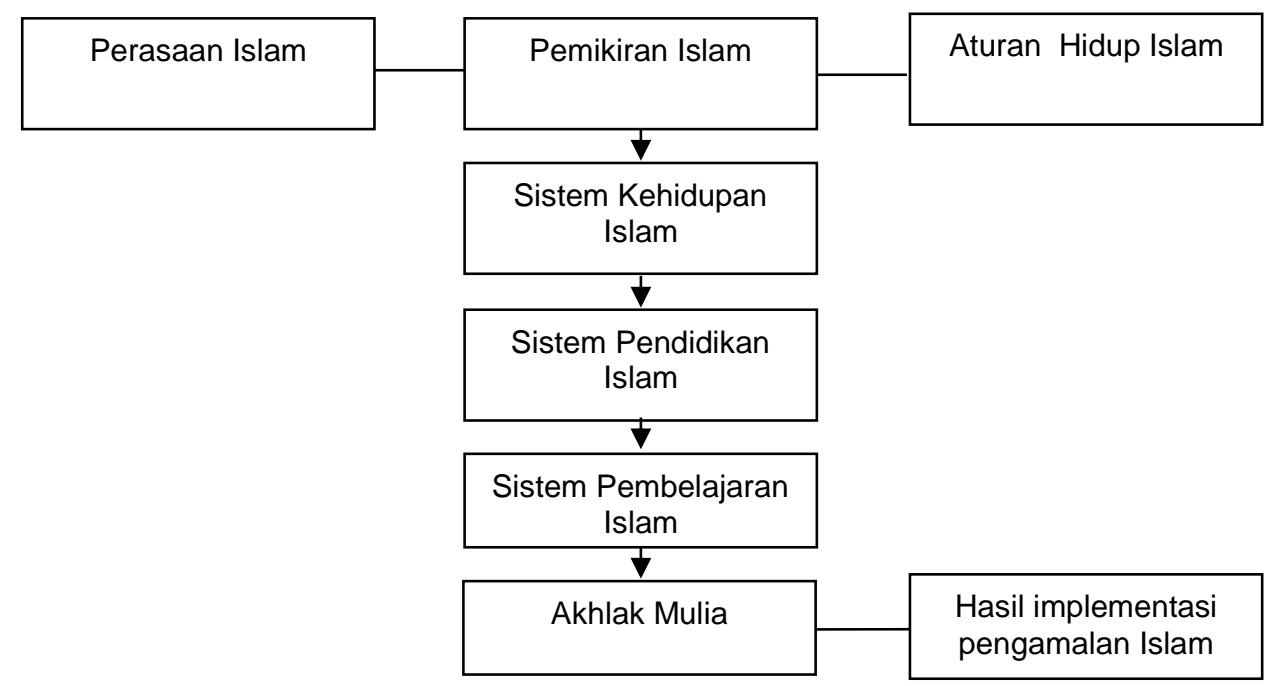

Gambar 2. Implementasi dalam membina akhlak mulia

\section{KESIMPULAN}

Posisi akhlak dalam pendidikan Islam merupakan buah dari pengamalan ajaran Islam secara kaffah. Akhlak terlahir tidak dengan sendirinya, tetapi merupakan realisasi dari pengamalan ajaran Islam secara terintegrasi yang mencakup aspek akidah, syariah, dan akhlak. Oleh karena itu, supaya terwujud lulusan yang memiliki karakter akhlak mulia mesti difasilitasi oleh sistem pendidikan yang mampu mewujudkan ke arah sana, dan sistem pendidikan tersebut harus terlahir dari sistem kehidupan yang berdasarkan pemikiran, perasaan, dan aturan hidup yang sama, yakni Islam. Dengan cara demikian, pendidikan di Indonesia akan lebih baik dan bisa melahirkan calon-calon pemimpin yang akan memimpin dunia serta memiliki karakter akhlak mulia.

\section{Daftar Pustaka}

Abdurrahman, H. (2018). Nizham Fi Al-Islam Pokok-Pokok Peraturan Hidup Dalam Islam. Bogor: Al-Azhar Press.

Aji, W. (2013). Kasus Tawuran Pelajar Jakarta Terus Meningkat Tahun Ini.

Al-Syaibany, O. M. al-T. (1979). Falsafah Pendidikan Islam. Jakarta: Bulan Bintang.

Bafadhol, I. (2017). Pendidikan Akhlak Dalam Perspektif Islam. Jurnal Edukasi Islami, 6(12), 45-61.

Candra, A. (2014). Fakta HIV AIDS Ini Wajib Diketahui Remaja. Retrieved December 2, 2016, from http://health.kompas.com/read/2014/01/24/0944493/Fakta.HIV/AIDS.Ini.Wajib.Diketahui.Remaja.

Ernita Dewi. (2011). Akhlak dan Kebahagiaan Hidup Ibnu Maskawaih. Jurnal Substantia, 13(9), 257-266. https://doi.org/10.1017/CB09781107415324.004

Faida, A. (2015). Implementasi Pembelajaran Aqidah Akhlak Dalam Pembentukan Karakter Siswa (Studi Multi Kasus di MIN Pundensari dan MI Plus Sabilul Muhtadin Pakisrejo Rejotangan Tulungagung). Tulungagung: IAIN Tulungagung.

Hamim, N. (2014). Pendidikan Akhlak : Komparasi Konsep Pendidikan Ibnu Miskawaih dan Al-Ghazali. Ulumuna Jurnal Studi Keislaman, 18(1), 21-40.

Hidayat, T., Rizal, A. S., \& Fahrudin. (2018a). Peran Pondok Pesantren Sebagai Lembaga Pendidikan Islam di Indonesia. Ta'dib : Jurnal Pendidikan Islam, VII(2), 1-15. Retrieved from https://ejournal.unisba.ac.id/index.php/tadib/article/view/4117/2485

Hidayat, T., Rizal, A. S., \& Fahrudin. (2018b). Pola Pendidikan Islam di Pondok Pesantren Mahasiswa Miftahul Khoir Bandung Dalam Membentuk Kepribadian Islami. Ta'dib : Jurnal Pendidikan Islam, VII(1), 9-19. Retrieved from https://ejournal.unisba.ac.id/index.php/tadib/article/view/3770/2247

Hidayat, T., \& Suryana, T. (2018). Menggagas Pendidikan Islam : Meluruskan Paradigma Pendidikan di Indonesia. Jurnal Pendidikan Islam Indonesia, 3(1), 75-91. Retrieved from http://ojs.ppsibrahimy.ac.id/index.php/jpii/article/view/133/93 
Hidayat, T., \& Syafe'i, M. (2018). Filsafat Perencanaan dan Implikasinya dalam Perencanaan Pembelajaran Pendidikan Agama Islam di Sekolah. Lentera Pendidikan, 21(2), 188-205. https://doi.org/https://doi.org/10.24252/lp.2018v21n2i5

Kristanti, E. Y., \& Susila, S. B. (2012). Menkes: 2010, 2 Juta Remaja Lakukan Aborsi.

Lubis, A. S. (2012). Konsep Akhlak Dalam Pemikiran al-Ghazali. Hikmah, VI(1), 58-67.

Maghfiroh, M. (2016). Pendidikan Akhlak Menurut Kitab Tahzib Al-Akhlaq Karya Ibnu Miskawaih. Tadris, 11(2), 76-89.

Mahfudhi, A. (2016). Konsep Pendidikan Menurut Ibnu Miskawih ( Transformasi Antara Filsafat dan Agama ). Jurnal Studi Islam, $3(1), 1-8$.

Maulida, A. (2013). Konsep dan Desain Pendidikan Akhlak Dalam Islamisasi Pribadi dan Masyarakat. Edukasi Islami Jurnal Pendidikan Islam, 2, 358-375.

Murdaningsih, D. (2015). Duh, 14 Juta Remaja Pernah Konsumsi Miras. Retrieved January 31, 2019, from http://www.republika.co.id/berita/nasional/umum/15/03/09/nkxtfw-duh-14-juta-remaja-pernah-konsumsi-miras

Muthoharoh. (2014). Konsep dan Strategi Pendidikan Akhlak Menurut Ibnu Miskawaih dalam Kitab Tahdzib Al-Akhlak. Skripsi. Semarang: Institut Agama Islam Negeri (IAIN) Walisongo. Retrieved from http://eprints.walisongo.ac.id/5416/1/103111076.pdf

Pengguna Narkoba di Kalangan Remaja Meningkat. (2013). Retrieved January 31, 2019, from http://regional.kompas.com/read/2013/03/07/03184385/Pengguna.Narkoba.di.Kalangan.Remaja.Meningkat

Rizal, A. S. (2015). Orientasi dan Konteks Sosial Pendidikan Islam (Memahami Dimensi Eksiologis Pendidikan Islam). Jurnal Pendidikan Agama Islam - Ta'lim, 13(1), 1-15.

Rizal, A. S., \& Anjaryati, F. (2016). Character Building: Telaah Pemikiran Ibnu Miskawaih Tentang Pendidikan Karakter. Jurnal Pendidikan Agama Islam - Ta'lim, 1(1), 111-118.

Robiatul Adawiyah. (2017). Konsep Pendidikan Akhlak Ibnu Miskawaih. Jakarta: Universitas Islam Negeri (UIN) Syarif Hidayatullah.

Saputra, A. (2014). Konsep Pendidikan Akhlak dan Implikasinya Dalam Pendidikan Agama Islma (Studi atas Pemikiran Syed Naquib Al-Attas dan Ibnu Miskawaih. Yogyakarta: Universitas Islam Negeri Sunan Kalijaga.

Subekhi, A. (2016). Parah Akibat Seks Bebas 47 Siswi di Ponorogo Hamil. Retrieved January 31, 2019, from http://daerah.sindonews.com/read/1129869/23/parah-akibat-seks-bebas-47-siswi-di-ponorogo-hamil-1470728031

Suherman. (2016). Pendidikan Akhlak Dalam Perspektif Islam. Jurnal An-Nur, 3(02), 117-133.

Usman, I. K. (2001). Konsep Pendidikan Ibnu Miskawaih dan Ibnu Khaldun, 1-16.

Zamroni, A. (2017). Strategi Pendidikan Akhlak Pada Anak. Sswwa, 12(2), 241-264. 